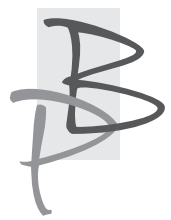

\title{
A decade of compulsory silence: Censorship of Edvard Kocbek's literature after his forced retirement
}

Summary: Edvard Kocbek was a renowned Slovenian writer who started writing already in his youth. In 1941, he became a member of the Liberation Front and the struggle against the occupiers. At the end of the war and shortly after it, he held important and esteemed positions in the power structure, but he lacked any real clout. After the political action taken against him in 1952, he was prevented from publishing his works for nearly a decade. Although Yugoslavia did not employ censorship in the form of formal bans at the time, the authorities would prohibit the publication of his poems, articles, or books behind the scenes. Through the archival documents of the most prominent political bodies in Slovenia, the present contribution outlines the manners in which this behind-the-scenes censorship was employed: at closed meetings, the authorities would decide what could not be printed, and the publish-

\footnotetext{
Aleš Gabrič - PhD in history, researcher at the Institute of Contemporary History, Ljubljana, Slovenia. His main research fields of interest include Slovenian political history, cultural history, history of censorship, and history of education. A selection of important publications: Socialisticna kulturna revolucija: slovenska kulturna politika 1953-1962 (The Socialist Cultural Revolution: Slovenian Cultural Policy 1953-1962) (published in 1995); V senci politike: opozicija komunistični oblasti v Sloveniji po letu 1945 (In the Shadow of Politics: Opposition to the Communist Power in Slovenia After 1945) (2019).E-mail: ales.gabric@inz.si
} 
ers and editorships had to comply with these decisions. These bans were not caused merely by the contents of Kocbek's works, based on the Christian and existential persuasion, but rather by the fear that because of his reputation, Kocbek could become the focus for the association of cultural workers of different persuasions and the formation of a group that could eventually become a significant political factor.

Key words: Edvard Kocbek, publication bans, hidden censorship, Slovenia.

\section{Dekada przymusowej ciszy: cenzura literatury Edvarda Kocbka po jego przymusowej emeryturze}

Streszczenie: Edvard Kocbek był znanym słoweńskim pisarzem, który zaczął pisać już w młodości. W 1941 roku został członkiem Frontu Wyzwolenia i walczył z okupantami. Pod koniec wojny i wkrótce po niej zajmował ważne i cenione pozycje w strukturze władzy, ale brakowało mu realnych wpływów. Po podjętej przeciwko niemu w 1952 roku akcji politycznej nie mógł nic publikować przez prawie dekadę. Chociaż Jugosławia nie stosowała wówczas cenzury w postaci formalnych zakazów, władze zabraniały publikowania jego wierszy, artykułów lub książek. Dzięki dokumentom archiwalnym najważniejszych organów politycznych w Słowenii można preśledzić sposoby, jakimi blokowano publikację tekstów Kocbka: na zamkniętych spotkaniach władze decydowały, co nie może zostać wydrukowane, a wydawcy i redakcje musieli zastosować się do tych decyzji. Zakazy te nie były powodowane jedynie treścią dzieł, opartą w większości na etosie chrześcijańskim i perswazji egzystencjalnej, ale raczej obawą, że ze względu na swoją reputację Kocbek może stać się człowiekiem-instytucją skupiającym wokół siebie pracowników kultury o różnych przekonaniach i przyczynić do sformowania grupy osób o znacznych wpływach politycznych.

Słowa-klucze: Edvard Kocbek, zakazy publikacji, ukryta cenzura, Słowenia. 
Edvard Kocbek (1904-1981) was a Slovenian poet, prose writer, essayist, author of critical and socially-engaged essays, and politician. Already as a grammar school and university student, he was a member of a circle of young Catholics who focused on social issues and rejected the rigid dogmatism of the Catholic Church. Kocbek's rejection of the Church tradition became evident already in 1927 when he dropped out of theology studies to study French at the Faculty of Arts in Ljubljana. During a study trip to France, he became acquainted with the work of leftist French intellectuals as well as attracted to the French personalism and existentialism in the philosophical and artistic sense. In 1937 he wrote an article on the Spanish Civil War, which provoked a crisis in Dom in svet (Home and World), the leading magazine of the Slovenian Catholic intellectuals. This circle of intellectuals became divided into two groups: one that supported the papal encyclicals on the danger of communism, and the other that - like Kocbek - deemed fascism and Nazism as the greatest contemporaneous threats. Kocbek started publishing his own magazine Dejanje (Action), attracting a younger generation of Catholic intellectuals and Christian socialist intellectuals who had similar outlooks on social issues as the Marxists. He analysed the resemblances between the social outlooks of Marxists and Christian Socialists, emphasising that the main difference between them was the Marxist materialist worldview, which neglected the spiritual side of human existence.

After the attack on Yugoslavia in April 1941, the swift capitulation of its army, and the division of Slovenia among the occupiers, Kocbek promptly joined the liberation movement. The Liberation Front, established at the end of April at the initiative of the Communist Party of Slovenia, was soon joined by a large number of rebellious Slovenian men and women. The Christian Socialists were one of its founding groups, and Edvard Kocbek assumed important functions in the resistance movement. Decades later, Kocbek revealed to Andrej Inkret, a young literary critic (who then published the best monograph on Kocbek in 2011), that he considered writing an autobiography. Kocbek planned to write the work he would never finish as a book in two parts: first, he would address before he joined the Partisan movement as a "question", and then the resistance and Partisan movement as the "answer"1.

\footnotetext{
1 A. Inkret, In stoletje bo zardelo: Kocbek, življenje in delo, Ljubljana 2011, Modrijan, s. 11.
} 
As a politician and member of the resistance movement's leadership, Kocbek stemmed from the positions established at the beginning of the resistance in 1941, when the Liberation Front in Slovenia was formed as a coalition. Even after the Communist Party of Slovenia as the main organiser of the resistance had usurped the key mechanisms of power, Kocbek kept returning to the ideas of the movement's coalition structure from 1941 and insisted on the ideological independence of the Christian Socialist group in the Liberation Front. After the war, he remained in politics, but the communists pushed him to less critical positions in the power structure. They became increasingly bothered by Kocbek's public appearances, during which he kept reiterating his positions and demands that the Christian Socialists be allowed to engage in independent ideological activities. The leading Slovenian communists, however, did not allow the Christian Socialists to establish their own publishing house and magazine, as Kocbek proposed on many occasions, but rather increasingly restricted the public expression of their views while surrounding Kocbek with secret police agents. Kocbek was deemed a political threat, though not on his own, as the secret police reports contained unquestionable findings that he was not thinking about organising an independent party and had remained loyal to the concept of the Liberation Front. The leading communists were more afraid of the possibility that a group of people, dissatisfied with the new regime, would start to gather around Kocbek because of his reputation and pressure him into finally making a resolute political move ${ }^{2}$.

Despite numerous conflicts with the leading communists, Kocbek persisted in politics, although without any real political power. In order to push him even further away from politics, they supported his literary activities. In 1949, one of the leading publishing houses, Državna založba Slovenije, published Kocbek's book Tovarišija (Comradeship), which contained his diary notes and additional commentaries from the Partisan period between May 1942 and May 1943. Kocbek's diaries, which he kept diligently for several decades - even in the most extreme battlefield conditions - represent a rich legacy and one of the best reflections of the spiritual milieu of his time. The communist ideologues, who were persistently building a different image of

2 A. Gabrič, Na ostrem robu med pozicijo in opozicijo, [w:] Krogi navznoter, krogi navzven: Kocbekov zbornik, red. N. Grafenauer, Ljubljana 2004, s. 146-157. 
the resistance in which they had supposedly played an almost exclusive role, were not especially enthusiastic about his reminiscences on the initial phase of the liberation struggle when the spirit of a coalition and cooperation had still prevailed between the ideologically different groups in the Liberation Front. Kocbek's next book Strah in pogum (Fear and Courage), published by the Državna založba Slovenije publishing house in 1951, garnered more attention in Slovenia than Tovarišija. In this collection of four short stories, written under the influence of existentialism, Kocbek focused on the difficult war dilemmas that people face when choosing between their conscience and historical mission. By opposing the black-and-white simplification of the Partisan movement, Kocbek triggered reactions leading to the end of his participation in the political scene.

The book Strah in pogum was certainly not the main cause for the retaliation, prompted by the leading Slovenian communists. It was more of an excuse that presented a convenient opportunity for them to remove from any essential functions the last Christian Socialist who insisted on supporting the initial positions of the group from the beginning of the liberation struggle in 1941. The affair that followed the publication of the book was just a part of the broader retaliation against the Catholic Church and its thinkers in 1952. It was a consequence of the tense relations between Yugoslavia and the Vatican, which even led to the severance of diplomatic relations at the end of 1952. The internal political consequences in Slovenia entailed the cancellation of the gazettes of both dioceses, final elimination of religious instruction from school curriculums, removal of the Faculty of Theology from the public educational system, and retribution against certain Catholic intellectuals (the affair after the publication of Kocbek's book Strah in pogum was the most resounding one by far). The criticism aimed against Kocbek was carefully planned. Boris Ziherl was in charge of the media campaign as the head of the Agitprop (the secret censorship apparatus of the Central Committee of the Communist Party of Slovenia). After the abolishment of this censorship apparatus at the end of 1952, when the Communist Party was renamed as the League of Communists and the media control somewhat relaxed, Ziherl became a target of the critiques of the Slovenian intellectuals, who reproached him with "Zhdanovism", i.e. imitating the principles of the Soviet cultural policy in Stalin's era. At the beginning of 1952, Ziherl incited attacks and 
newspapers started to publish offensive and rude critiques of Strah in pogum ${ }^{3}$. Due to the media lynch and the political pressure exerted by the leading politicians, in March 1952 Kocbek resigned from all positions. Although he was (only) 48 years old, he agreed to the proposal to retire because the leading Slovenian politicians promised him the chance to freely publish his literary works once he withdrew from politics.

After the forced retirement, Kocbek quickly realised that his former colleagues would prevent him from publishing his works despite their promises. In October 1951, a few months before the retaliation would begin, the programme of the Državna založba Slovenije publishing house for 1952 still contained the book "Partizanski dnevnik" (Partisan Diary), which Kocbek was preparing 4 . He was therefore in the process of negotiating the publication of a sequel to the 1949 book Tovarišija with the publishing house that had already published two of his books. Soon after the retaliation, Kocbek realised that the publication of his Partisan memoirs (later titled Listina) was uncertain. Instead, the publisher advised him to start translating from French, as it would gladly publish his translations of Guy de Maupassant ${ }^{5}$.

In the three years following the political showdown, Kocbek's name was used in public for the exclusive means of political provocation or affront. During the public debate on the acceptability of jazz on the music scene, Mitja Vošnjak appeared among the advocates of the Party's cultural policy who believed that jazz should be banished from the Slovenian cultural scene. In his article, published on 9 May 1952 in Slovenski poročevalec, the daily newspaper with the largest circulation in Slovenia, Vošnjak wrote that listening to the jazz advocates was equally absurd as demanding "that Kocbek's Strah in pogum be included among the obligatory reading material for schools"6. The leading Slovenian newspapers also ignored Kocbek's fiftieth birthday on 27 September 1954. It was, however, mentioned in Naši razgledi (a journal that

3 Tegoż, Slovenska agitpropovska kulturna politika 1945-1952, "Borec" 1991, 43 (No. 7-9), s. 628-634; I. Omerza, Edvard Kocbek: osebni dosje št. 584, Ljubljana 2010, Karantanija, s. 67-116.

4 Arhiv Republike Slovenije, Centralni komite Zveze komunistov Slovenije (hereinafter: SI AS 1589), III, t. e. 30, Zapisnik seje podkomisije za agitacijo in tisk, 13 October 1951.

5 E. Kocbek, Dnevnik 1951-1952. Zagreb 1987, Globus, s. 197.

6 M. Vošnjak, Amater in jazz, "Slovenski poročevalec" 9 May 1952, 13 (No. 109), s. 2. 
focused on the deliberations and reviews of topical cultural and scientific matters and was intended for the more demanding readers) on 23 October 1954, against the wishes of the leading Party ideologues ${ }^{7}$. A week later, at the session of the Press Commission of the Socialist Alliance of Working People of Slovenia (since 1953, this had been the new name of the Liberation Front of Slovenia), Bojan Štih as the author of the contribution and the representative of the journal's editorship was reproached by Boris Ziherl merely for this brief mention of Kocbek's anniversary: "It appeared slightly odd how you celebrated Kocbek, which is a mistake and people believe it was a little too much"». Kocbek also found out about the disagreement and wrote more about it in his diary than what was included in the session minutes. He received the information that Štih responded to the critique resolutely with the following words: "Is it my fault that he was born and that he is like he is?"

Not only was Kocbek's name marred by the Party ideologues: it was also used to attack them. In the Svit magazine, which was published by a younger literary generation and ceased its activities in 1954 due to political pressures, Stanko Jarc harshly criticised the leading Slovenian Party ideologues for reproaching this magazine's creative achievements. As an example of their nonsensical interpretations of literature, Jarc also mentioned Kocbek and used the cultural-political vocabulary of these narrow-minded ideologues: "Edvard Kocbek thus marches in this carnival parade with a rounded belly, dressed in a black cassock, repenting for his great sins like medieval flagellants. With his 'typical' progressive plumpness he still looks more like Galileo (E pur si muove), despite the shiny inscription 'Reactionary of the clericalist type' on his back." 10 Such sarcastic remarks represented a ruthless assault against the mentality of the Party ideologues. No wonder that this article was published in the very last issue of the Svit magazine before it was cancelled.

7 Štirje jubileji, "Naši razgledi” 23 October 1954, 3 (No. 20), s. 13.

8 Arhiv Republike Slovenije, Republiška konferenca Socialistične zveze delovnega ljudstva Slovenije (hereinafter: SI AS 537), file 38, zapisnik 14. seje Komisije za tisk pri SZDLS, 30 October 1954, s. 10.

9 A. Inkret, 1961 - Kocbekova vrnitev v javnost, "Nova revija" 1992, 11 (No. 126-127), s. 1204-1205.

10 S. Jarc, Mnogo let prepozno ... ali prezgodaj, "Svit” 1954, 3 (Last issue), s. 208-209. 
The rare mentions of Kocbek's name in public during the first three years after his retirement therefore mostly served as a means of expressing the political views of the political opponents. During that time, Kocbek signed a few translations from French and a few of his own poems, published in some of the less prominent newspapers. However, he refrained from signing the more important articles, published in the middle of the 1950s in Nova pot (New Way), a Catholic priests' society magazine. The articles were signed as M.M., yet the authorities were well aware of the author's true identity. The article Krščanske misli o marksistični morali (Christian thoughts on Marxist morality), published in the Nova pot magazine in the middle of 1958, was the first article by Edvard Kocbek signed with the initials E.K.

As of his resignation from all functions in 1952, Kocbek kept receiving unreliable information that he would be allowed to publish his works again as long as they did not contain anything that the authorities would deem as politically questionable. This, however, did not depend only on Kocbek's own work, but rather on the broader circumstances of his return to the public sphere. Moreover, he could not know how reliable the information was and who was behind it. For example, Drago Šega, who took over the editorship of the leading Slovenian literary magazine Naša sodobnost (Our Modernity) in the summer of 1955, mentioned decades later that Vida Tomšič, a member of the innermost Slovenian Party leadership, had explicitly warned him that "any participation of Kocbek's in the magazine is out of the question"11.

In the middle of the $1950 \mathrm{~s}$, people who did not believe that even the slightest difference of opinion represented a threat to the communist political monopoly and who did not possess such a narrow-minded outlook on the increased diversity of scientific and cultural activities as the older ideologues started gaining importance in the Slovenian political leadership. The changes led to the decline of the cultural-political orientation, symbolised by Boris $\mathrm{Zi}$ herl in Slovenia and labelled as Zhdanovism by his critics from the ranks of intellectuals. Boris Kraigher, the President of the Slovenian Government at the time, and Stane Kavčič, who held that position a little more than a decade later, were both economic reformers. As such, they were among those leading

11 A. Inkret, D. Šega, Pet pisem, “Ampak (supplement of Nova revija)” 1992, 11 (No. 117118), s. 35. 
communists that supported a more tolerant attitude towards the intellectuals, as they were aware that it was not possible to accelerate the economic and social modernisation without the cooperation of experts. Naturally, the more "liberal" communists set the limits of acceptability as well and were very sensitive about any activities that they deemed as excessively political. However, the limits of acceptability were expanding. In the second half of the 1950s, the League of Communists of Slovenia gave up the strict control over amateur cultural creativity as well as allowed more cultural freedom for jazz, abstract art, experimental theatre, and modern literary trends. Slovenia started gaining a reputation among the intellectuals in Yugoslavia (and later also in the broader circle of communist countries) that persisted until as late as the dissolution of the Eastern European communist system: it was seen as the part of the state where more was permitted than elsewhere.

By no means does this mean that in Slovenia no scandals took place on the cultural scene or that no intellectuals were convicted and their works prohibited. However, the indications that it would soon become possible to publish contents banned only a couple of years ago also reached Kocbek in the spring of $1955^{12}$. The largest publishing house - Državna založba Slovenije from Ljubljana - resumed the negotiations to publish Kocbek's second book, based on his wartime diary entries. Kocbek offered his collection of poetry Prevod iz groze (A Translation of Horror) to the Založba Obzorja publishing house from Maribor, while the Mohorjeva družba publishing house from Celje was to publish his cycle of twelve poems in its calendar for the year 1956.

The question of the attitude towards Edvard Kocbek was thus revisited in the discussions held by the highest political forums. In the third case - when Kocbek attempted to publish his poems in the Koledar Družbe sv. Mohorja za prestopno leto 1956 calendar, an affair broke out that prompted a political response. This publishing house was established in 1851 by the Slovenian clergy and preserved its Catholic character under the communist reign. A new act on publishing companies, adopted in 1955, enabled the authorities to increase the pressure on the publishing houses and establish the foundations to control even those publishers that had previously remained outside their direct influence. Apart from the magazines of the younger generation of intellectuals,

12 A. Inkret, 1961 - Kocbekova vrnitev v javnost, dz. cyt., s. 1205. 
the Družba sv. Mohorja publishing house was a prominent target of Slovenian politics. It refused to abide by the act providing for the inclusion of the representatives of the authorities among the members of the editorial board. The authorities would thus gain insight into the publishing programme and the ability to influence it, as well as exercise preventive censorship. Without the registration of activities according to the new statutory requirements, the existence of the oldest Slovenian publishing house hung by a thread: Slovenian politicians even considered its liquidation.

The question of the attitude towards Edvard Kocbek snuck into these deliberations due to a decision made by the director of the printing house in Celje, which printed the publications of the Družba sv. Mohorja publishing house. According to the known documentation, he made an arbitrary demand without any political encouragement from above - to remove Kocbek's poems from the Družba sv. Mohorja calendar for 1956. The editor of the publishing house received a letter that would soon become the subject of lively debates in the cultural community due to the extraordinarily rude and tactless tone in which the director of the printing house put himself in the role of the supreme censor: "As the director of the printing house, I will not allow the reputation that the collective under my leadership has gained through its hard work in Slovenia and abroad to be ruined. Therefore I demand that you remove all of Kocbek's poems from the calendar and replace them with more sensible matters that will benefit your subscribers. For as long as you refuse to do so, we will not proceed with the printing of the calendar." 13

The printing was by no means suspended only because of the attempt to publish Kocbek's poems. The main reason was that Družba sv. Mohorja was the only publishing house in Slovenia that had not adapted to the new legislative requirements by November 1955, when this scandal broke out. This problem was also the central theme of the conversation held on 3 December 1955 by Stanko Cajnkar, the secretary of the publishing house, and Boris Kocijančič, the Minister of Culture of Slovenia and the President of the Government Commission for Religious Matters. Naturally, they were unable to avoid touching upon the unpleasant affair that had broken out because the publishing of

13 SI AS 537, t. e. 27, Seja predsedstva Socialistične zveze delovnega ljudstva Slovenije, 12 January 1956, s. 35. 
Kocbek's poems, which had already been agreed upon, had been prohibited. Minister Kocijančič considered some of Kocbek's poems as explicitly political and made it very clear to Cajnkar that he should not publish them. In Kocijančič's opinion, two poems were "as far as their content is concerned - to put it mildly - adverse to us; for the second poem 'Veliki petek' (Good Friday) I can say that it is hostile towards us and that its content is distinctively favourable towards the White Guard. (...) I should emphasise that this is not some kind of affront to Kocbek, but rather the question of the contents that are by no means suitable for the calendar, which, for this reason, cannot be published in such a form. Thus the printing of the calendar shall be suspended until the editorial board reviews the calendar and vouches for its contents." Cajnkar opposed Kocijančič: he claimed that Kocbek's poems could be interpreted in various ways and that Kocbek "did not see or understand them in the same manner as you do". However, the Minister of Culture insisted: in unambiguous terms, he told the secretary of the Družba sv. Mohorja publishing house that in order to keep operating, it had to appoint an editorial board that would comply with all the provisions laid down by law. This, however, would allow the authorities to control the activities of the publisher. As he reported the discussion to the President of the Government Boris Kraigher, Kocijančič mentioned that Cajnkar "realised that I was informing him of standpoints that were already definite." ${ }^{14}$ Regarding Kocbek, this meant that his poems would not be published in the calendar, as their inclusion would not be confirmed by the new editorial board (which the Družba sv. Mohorja publishing house had to appoint whether it wanted to or not in order to keep working). Furthermore, the publisher had to change its name: since that time, it operated as the Mohorjeva družba publishing house.

Kocbek did not know much about the circumstances of the affair. Angered by the arbitrary move of the printing house director, on 7 December 1955 he asked Stanko Cajnkar how it was possible that the poems became inappropriate as late as six months after they had been submitted to the editorship, once they had already been prepared for printing. He summed up his point of view in the following assessment: "The director's actions are

14 Arhiv Republike Slovenije, Vlada Republike Slovenije (hereinafter: SI AS 223), t. e. 632, 301/55, Uradni zaznamek o razgovoru tov. Kocijančiča z dr. Cajnkarjem, 3 December 1955. 
arbitrary because he invented a senseless explanation, offensive to all the dead heroes and living officials, for unknown reasons. On top of everything, he imposed this explanation as a kind of a political censorship decision and simply condemned all twelve poems instead of turning to the author for an explanation or leaving the issue to other people and institutions, far more competent for such a task." 15

The political leaders adopted the final decision regarding this complicated issue at the Presidency of the Socialist Alliance of Working People of Slovenia session on 12 January 1956. They resolved not to give in an inch to the Mohorjeva družba publishing house. The assessment that Kocbek's case was "merely a side effect" confirmed that the ban on Kocbek's poems was, on this occasion, merely collateral damage. The leading Slovenian politicians criticised the director of the Celje printing house as well, as such vulgar and tactless political moves could trigger negative public responses and support the allegations of the political dictate regarding culture. The President of the Slovenian Government Boris Kraigher proposed "that we should not make an issue out of this unfortunate letter by the director of the Celje printing house" and added that he would simply need to be replaced. He himself opposed the publication of Kocbek's poems because they would be printed in a clearly ecclesiastical publication with a particular worldview, which could be, in the political sense, also understood as an association of the opponents of the Marxist outlook on the world. The discussion of the leading politicians did not stop at this point. Instead, it expanded and touched upon the possibility of Kocbek's works being published by other publishers. Boris Kraigher also mentioned the poetry collection that Kocbek had sent to a publisher in Maribor: "However, I know that Kocbek has also sent a collection of his poems to the Obzorja publishing house in Maribor, but he described them with such a motto that I would never print them if it were up to me. His motto states that he has been deceived and that his tired heart has been left on the precipice." Kraigher felt that in his poetry collection, Kocbek wished to hint that the Christian socialists had "joined the national liberation struggle in order to protect God". Stane Kavčič even intensified this assessment, stating "that this collection comes across as a lamentation

15 SI AS 223, t. e. 642, 88/59, Pismo Edvarda Kocbeka - Stanku Cajnkarju, 7 December 1955. 
for all the White Guard members that had fallen in the Suha krajina region, in particular if one is unfamiliar with the subject"16. The exceedingly political evaluations of Kocbek's poetry were very different from Kocbek's actual opinions, as he never renounced his Partisan past and was extremely proud of it. Behind the scenes, the opinions of the politicians reached those who made decisions concerning the publishers' programmes. The signal that the time was not right yet was strong enough that all publishers, one after another, rejected the publication of Kocbek's works.

A couple of years went by again. In 1957, Kocbek received news that two of the most prominent Slovenian politicians, Edvard Kardelj and Boris Kraigher, supported the publication of the sequel to Tovarišija (Comradeship) ${ }^{17}$. However, the political circumstances in the state intervened once again. In April 1958, the Congress of the League of Communists of Yugoslavia took place in Slovenia (in Ljubljana) for the first time, and for the first time after the war, the Slovenian communists addressed the question of the national relations in Yugoslavia. Officially, these relations had been deemed as resolved once and for all as of the year 1945 and the federal transformation of the state. However, new tensions had arisen at the end of the 1950s. After the notable dispute between the Serbian writer Dobrica Ćosić and the Slovenian literary historian and comparativist Dušan Pirjevec in 1961/62, Slovenian politics opened the door widely for such discussions that had previously been undesirable ${ }^{18}$. Furthermore, 1958 was the year of another retaliation against the humanist intelligentsia, which the authorities had started to see as a potential rallying point of the opposition ${ }^{19}$.

In those times, the printing of books by politically questionable authors depended primarily on the political circumstances: 1958 was truly not conducive to the publication of the second book based on Kocbek's Partisan diary entries. Kocbek's assessments on the neglect of Slovenia in Yugoslavia were gener-

16 SI AS 537, t. e. 27, Seja predsedstva Socialistične zveze delovnega ljudstva Slovenije, 12 January 1956, s. 33-40.

17 A. Inkret, 1961 - Kocbekova vrnitev v javnost, dz. cyt., s. 1206.

18 A. Gabrič, Socialistična kulturna revolucija: slovenska kulturna politika 1953-1962, Ljubljana 1995, Cankarjeva založba, s. 345-353.

19 Tegoż, V senci politike: opozicija komunistični oblasti v Sloveniji po letu 1945, Ljubljana 2019, Cankarjeva založba, s. 212-220. 
ally known, and various groups of intellectuals that the state police deemed as politically suspicious kept trying to get him to participate in their magazines. Therefore the fact that his book Listina (The Document) was "explicitly commissioned by the Državna založba publishing house", as he wrote in March 1959, did not help Kocbek ${ }^{20}$. Even the leading Yugoslav ideologue Edvard Kardelj allegedly agreed with the book's release. However, as Boris Kraigher explained to his colleagues from the Slovenian Party leadership, this assumption had resulted from inadequate information. After Vida Tomšič spoke with Kardelj as well, the latter changed his standpoint ${ }^{21}$. The editorial board of the Državna založba Slovenije publishing house did not have a united standpoint regarding the publication of Listina: it was particularly the president of the board that opposed it, and until the end of the summer of 1959, the publishing house had not yet reached a final decision regarding the printing of the book ${ }^{22}$. As political problems already loomed on the horizon, the most important political body - the Executive Committee of the Central Committee of the League of Communists of Slovenia - assumed control and thoroughly discussed the matter on 5 September 1958.

Vida Tomšič relayed the internal information from the publisher and mentioned that "this decision cannot be made by the editorial board alone, because political evaluations will follow any rejection of the book". She explained that in case the book was printed, an image of the liberation struggle unlike the one promoted by the communists would become public. Supposedly it was disputable that the communists might come across as untrustworthy, as they had made certain promises at the onset of war, but later double-crossed the other groups in the Liberation Front and ensured a political monopoly for itself. According to Tomšič, the book's subtitle Znamenja (Signs) that Kocbek used at the time was "symbolic and refers to the signs predicting a variety of future events, including the bureaucratisation of the revolutionaries and everything else, as it happened in the Soviet Union. The book also discusses the inappropriate attitude of the communists towards

20 SI AS 223, t. e. 642, 88/59, Pismo Edvarda Kocbeka - Borisu Kraigherju, 12 March 1959.

21 SI AS 1589, IK, t. e. š. 8, Zapisnik seje izvršnega komiteja CK Zveze komunistov Slovenije, 5 September 1958, s. 24.

22 A. Inkret, 1961 - Kocbekova vrnitev v javnost, dz. cyt., s. 1206-1207. 
the Christian group and the farsighted neglect of this group, particularly of Kocbek himself, regarding certain fundamental questions of our development." In Vida Tomšič's opinion, Kocbek constantly over-emphasised the relations between the communists and Christians. The communists would keep assessing his standpoint "that the sanctity of human life is the highest moral norm, and therefore we have no right to judge" through the perspective of the bloody retaliation against the collaborating military units during the war and the execution of prisoners and civilians shortly after it. Therefore, this resulted in the evaluation that "in this book, the White Guard members became martyrs of sorts." Kocbek's claims were supposedly also wrong because he opposed the division of Slovenians into several categories, which led Tomšič to believe that Kocbek indirectly demanded that "therefore, the entire Slovenian nation has the right to take part in the government and differentiation is not pertinent". Regarding the relations between Slovenia and Yugoslavia, the book exhibited the standpoint that Kocbek had already articulated regarding the higher level of development and standard in Slovenia, which is why the author "has kept expressing his characteristic reservations about the integration of Slovenia into the Yugoslav community ever since 1943". Apart from the issue of the relationship between Marxism and Christianity, Kocbek allegedly developed the same outlooks in his book as in the aforementioned contribution Krščanske misli o marksizmu (Christian Thoughts about Marxism), published in 1958 in the Nova pot magazine "that Marxism is amoral because it is based on materialism". Ostensibly, this part also represented an indirect critique of the Programme of the League of Communists of Yugoslavia, adopted at the congress in Ljubljana. Tomšič proposed that her colleagues in the Party leadership order the publishing house to reject the printing of the book for two reasons. The first reason was a banal assessment that the book "is dubious and actually untrue even as a document", while the second point was that it purportedly represented a revision of the Marxist principles based on the Western European bourgeois viewpoints. According to Vida Tomšič, Kocbek shared certain outlooks with the most widely-known Yugoslav dissident Milovan Đilas, even though she did not equate them. With their view that Marxism was incapable of liberating people, both of them supposedly indicated that the authorities should revise their standpoint regarding private property and stop promoting a single ideological concept: 
"That means that more ideologies should be allowed aside from the ruling one, which essentially leads to multi-party concepts." 23

Vida Tomšič's proposals triggered a lively discussion, revealing the various tactics that the communists would resort to in case of such political difficulties. While the authorities activated all of the propaganda machinery and attacked Kocbek openly during the conflict with him in 1952, in 1958 they decided that there was no longer any point in making a martyr out of him. Instead, they preferred to resolve the situation quietly without making a fuss in public. As a cool-headed political pragmatist, Boris Kraigher assessed that "the current international political situation would not be conducive to an open conflict with Kocbek" and that such a move would first need to be coordinated with the leadership of the League of Communists of Yugoslavia. However, he advised against it and proposed that the publisher should simply be instructed to demand of Kocbek to correct certain parts of his book. As Kocbek would undoubtedly reject that, the book would simply not be included in the programme. Should Kocbek attempt to publish his work in Trieste, with the Slovenians in Italy, or elsewhere abroad, they would just let it slide quietly. The authorities would not argue against Kocbek's articles published in the Nova pot magazine, as this would only result in the popularisation of a magazine "with a limited print run, intended for a narrow circle: the Slovenian Catholic priests. Therefore it would be wrong to promote this publication by publishing our response in it." However, the editor should be summoned for a discussion and told "that, should it keep publishing Kocbek's articles, his magazine will be cancelled". The other members of the Executive Committee of the Central Committee of the League of Communists of Slovenia agreed with Kraigher's proposal that everything should be settled behind the scenes, without any public discussions. On this occasion, Mitja Ribičič added that the printing of the book abroad should not represent a serious problem either, because "Even our citizens can print their works abroad. However, should they wish to import the book to our country, they will need an import license, which we can always refuse." 24

23 SI AS 1589, IK, t. e. 8, Zapisnik seje izvršnega komiteja CK Zveze komunistov Slovenije, 5 September 1958, s. 19-22.

24 Tamże, s. 22-25. 
Regarding the most controversial matter, the innermost leadership of the Slovenian communists concluded: "The Državna založba Slovenije publishing house should be recommended to refuse Kocbek's book 'Znamenja' as uninteresting." They also took into account the other proposals, made during the relevant discussion. Should the book be published abroad, it should simply be ignored and no attention should be paid to it. Only these sorts of standpoints should be argued against in public, but they should by no means be discussed directly with Kocbek. They confirmed that the editor of the Nova pot magazine would be summoned for a discussion and warned that it was inappropriate to publish Kocbek's articles ${ }^{25}$.

The decisive and united position of the Slovenian political leadership did not allow for any doubt regarding the outcome of the third attempt at publishing Kocbek's Listina or Kocbek's further association with the Nova pot magazine. Although he never received a written response, it was made clear to Kocbek in a telephone conversation, which "more than upset him", that his book would not be published. Already on the same day - on 16 December 1958 - Kocbek responded to the editor that he should not even try to blame him or anyone else for the complications when it was obvious what was going on: "It is the management of the Državna založba publishing house that is to blame, no one else. This would not be so improper if the censors read the manuscript normally and then either communicated their wishes or told me openly and clearly: we are sorry, but LISTINA cannot be published for this and that reason. Granted, such a decision would be incomprehensible, because people could legitimately ask themselves why The Goebbels Diaries can be published when Kocbek's Partisan diaries cannot, but at least it would have been honest in terms of the clarity of the response." 26

Kocbek's anger and claims of unfair and dishonest actions yielded at least one result: one month later, the publishing house finally managed to put together a written rejection. At the beginning of February 1959, Kocbek responded to the editorial board somewhat more calmly than to the editor two months

25 Tamże, s. 25.

26 SI AS 223, t. e. 642, 88/59, Pismo Edvarda Kocbeka - Cirilu Vidmarju, 16 December 1958. Joseph Goebbels's diary entries, mentioned in the letter, had been published in Maribor in 1958 under the title of Goebbelsov tajni dnevnik (The Goebbels Secret Diary). 
earlier. However, he nevertheless admonished it for interpreting his book in a distorted manner (which, naturally, followed the model from the session of the leadership of the League of Communists of Slovenia that Kocbek was not completely familiar with). Still, Kocbek was not willing to renounce his past and kept insisting on the viewpoints that he had joined the liberation struggle with. "I will fight against the rejection of my personal document and against such belittlement of my life with all the means dictated by my loyalty to the Partisan movement and socialism," Kocbek wrote in the conclusion of his answer to the publisher ${ }^{27}$.

Within a few months after the session, the rest of the decisions from the Executive Committee of the Central Committee of the League of Communists of Slovenia session of September 1958 were quietly implemented as well. Boris Kocijančič once again summoned the editor of Nova pot Stanko Cajnkar. At the beginning of January 1959, he advised him not to publish Kocbek's articles in the future ${ }^{28}$. At the end of February, Kocbek was interrogated by the police and accused of acting against the authorities. This upset him even further, and on 12 March 1959 he wrote directly to the President of the Government Boris Kraigher, as the rumours that were spreading about him started to "take on a fantastic form". After rejecting the political reproaches against him, Kocbek also touched upon his literary work in a very realistic evaluation: "I am well aware that seven years ago you punished me brutally and isolated me completely not because I refused the black and white technique of the previous writing, but because I, while being convinced especially of the unavoidability and righteousness of socialism, did not believe in its exclusive dogmatism. I also know that today's tensions do not stem from any political activities of mine, but rather from the fear that my Listina, true to the developments, instils in some people." 29

Kocbek then listed the chronology of the censorship of his works since his resignation in 1952. At that time, the editors started rejecting his contributions. His translations of thirty-eight short stories by Guy de Maupassant, already

27 SI AS 223, t. e. 642, 88/59, Pismo Edvarda Kocbeka - Založniškemu svetu Državne založbe, 5 February 1959.

28 A. Inkret, 1961 - Kocbekova vrnitev v javnost, dz. cyt., s. 1207.

29 SI AS 223, t. e. 642, 88/59, Pismo Edvarda Kocbeka - Borisu Kraigherju, 12 March 1959. 
commissioned by the publisher, were struck from the programme (they were published in 1959). However, what upset him the most was the "vandalism of the head of the Celjska tiskarna printing house, who took it upon himself to throw out twelve of my Partisan poems from the 1956 Mohorjeva družba calendar." Furthermore, Kocbek's works were excluded from several other planned publications. "I was thrown out of all the textbooks and deleted from the anthology of poetry that is being prepared in the French language. I am also ignored by other publishers, magazines, and radio, and a few weeks ago you prevented my further participation in the Nova pot magazine," Kocbek expressed his indignation at the humiliation that he had experienced to the President of the Government ${ }^{30}$.

Boris Kraigher did not understand the letter as an attempt at appeasing the situation as Kocbek wished. Instead, he assessed that the letter proved that the differences of opinions were now much more insurmountable than seven years earlier when the dispute had begun. Then Kraigher once again pointed out what Kocbek should definitely not mention in his writings: "I am convinced that the publishers will accept everything, provided that you finalise the negotiations with them and manage to avoid any topical political barbs." ${ }^{31}$

Despite the stern wording of his letter, Kraigher was aware that Kocbek was not really interested in engaging himself politically. What bothered the authorities, however, was that various generations of intellectuals, which maintained a more or less critical attitude to the authorities in their magazines, kept attempting to persuade Kocbek to participate. In 1958 and 1959, a notable retaliation against the younger intellectuals gathered around the Revija 57 magazine took place (the main target of the incident was Jože Pučnik, who received a long prison sentence at the time, while in 1990 he was the leader of the coalition that won the first multi-party elections in Slovenia). Simultaneously, the League of Communists of Slovenia strengthened its position in social sciences and humanities by removing the scientists it saw as too Christian-oriented from their positions and establishing new, more Marxist-oriented institutes, which were supposed to strengthen the Marxist outlook on the past and present ${ }^{32}$.

30 Tamże.

31 SI AS 223, t. e. 642, 88/59, Pismo Borisa Kraigherja - Edvardu Kocbeku, 28 May 1959.

32 A. Gabrič, Socialistična kulturna revolucija..., dz. cyt., s. 268-302. 
At the time when the authorities were pitted against the individuals with incompatible opinions, Kocbek's cooperation with the intellectuals of the "wrong" persuasion and his "erroneous" outlook on the recent past as well as the present were the reservations that decisively influenced the most recent delay in the publication of his works. During the action against the younger intellectuals, at the session of the innermost Slovenian political leadership, Kraigher openly explained that he did not believe "that Kocbek is the man who would want to mount any sort of a counter-revolution". He added, however, that it was wrong that "certain elements were using him as a signpost". If anyone should be seen as politically dangerous, then "this is completely true of Pučnik" 33.

Once again, Kocbek's literary endeavours disappeared and waited for the time when the political atmosphere was, in the opinion of the authorities, more appropriate for the publication of his works. This happened after the push against the humanist intelligentsia; after the outlooks on the past had changed; when every different evaluation of the Partisan years was no longer seen as opposition against the authorities; and when the criticism against the attempts at Yugoslav centralism even became a part of the official Slovenian politics. Such a relaxation took place at the beginning of the 1960s when Kocbek was informed by some of his acquaintances that Kraigher would no longer mind if he wished to start publishing again. Initially, a younger generation of artists invited Kocbek to participate. First, he arranged for the publication of a cycle of his poems with the editor of the Perspektive (Perspectives) magazine, founded in 1960 (it was published by roughly the same group of people as the Revija 57 magazine before it). Perspektive became famous as the most critical magazine of its time. It expanded its criticism from the cultural sphere, which the predecessors of this publication had done as well, to exceedingly political issues. The leading Slovenian politicians preferred that Kocbek's return to the public cultural scene should take place in Naša sodobnost - a magazine of the already distinguished cultural workers, much closer to Kocbek's own generation. After a long time, Kocbek's poems were once again published in one of the most important Slovenian magazines: in the July issue of Naša sodobnost in 1961. Since then, Kocbek was a regular contributor to this publication.

33 SI AS 537, t. e. 27, Seja predsedstva Socialistične zveze delovnega ljudstva Slovenije, 6 November 1958, s. 52-53. 
In the autumn of the same year, a cycle of Kocbek's poems was also published by the Perspektive magazine, while the Mohorjev koledar za leto 1962 calendar contained quite a few poems that had been excluded from the 1956 calendar. In 1963, the Slovenska matica cultural society also published Kocbek's poetry collection Groza (Horror), which he had attempted to publish with the Založba Obzorja publishing house in 1955 under the title Prevod iz groze (A Translation of Horror). However, it took four attempts to finally publish Listina (The Document) in 1967, based on Kocbek's diary entries from 1943. The work was published by the oldest Slovenian cultural and scientific society Slovenska matica, which included the book in its annual collection and thus ensured that the widest possible circle of readership was reached. No alarms were sounded by the political leadership because of Kocbek's return to the public cultural scene, and his case was no longer examined at the sessions of the leading political structures in the 1960s. At the time, Kocbek no longer qualified among the most pressing political problems. However, he was indeed still monitored by the associates of the police, who would regularly inform the innermost Slovenian political leadership of his actions and contribute reports to one of the most extensive dossiers of the Slovenian State Security Administration $^{34}$.

\section{Sources and literature}

\section{Archival sources}

$\mathrm{SI}$ - Archives of the Republic of Slovenia.

SI AS 223 - Government of the Republic of Slovenia.

SI AS 537 - Republic Conference of the Socialist Alliance of the Working People of Slovenia.

SI AS 1589 - Central Committee of the League of Communists of Slovenia.

34 Most information from the dossier published in: I. Omerza, Edvard Kocbek: osebni dosje št. 584 , dz. cyt. 


\section{Literature}

Gabrič A., Na ostrem robu med pozicijo in opozicijo, [w:] Krogi navznoter, krogi navzven: Kocbekov zbornik, red. N. Grafenauer, Ljubljana 2004, s. 146-159.

Gabrič A., Slovenska agitpropovska kulturna politika 1945-1952, [w:] „Borec” 1991, 43 (No. 7-9), s. 469-656.

Gabrič A., Socialistična kulturna revolucija: slovenska kulturna politika 1953-1962, Ljubljana 1995, Cankarjeva založba.

Gabrič A., V senci politike: opozicija komunistični oblasti v Sloveniji po letu 1945, Ljubljana 2019, Cankarjeva založba.

Inkret A., In stoletje bo zardelo: Kocbek, življenje in delo, Ljubljana 2011, Modrijan. Inkret A., 1961 - Kocbekova vrnitev v javnost, “Nova revija” 1992, 11 (No. 126127), s. 1198-1216.

Inkret A., Šega D., Pet pisem, "Ampak (priloga Nove revije)" 1992, 11 (No. 117$118)$, s. 34-39.

Jarc S., Mnogo let prepozno... ali prezgodaj, "Svit", 3 (Zadnja številka): 1954, S. $208-212$.

Kocbek E., Dnevnik 1951-1952, Zagreb 1987, Globus.

Omerza I., Edvard Kocbek: osebni dosje št. 584, Ljubljana 2010, Karantanija.

Štirje jubileji, “Naši razgledi” 23 October 1954, 3 (No. 20), s. 13.

Vošnjak M., Amater in jazz, "Slovenski poročevalec" 9 May 1952, 13 (No. 109), S. 2. 